\title{
The Relationship Between Emotional Intelligence Students Learning Achievement
}

\section{Enur Rohmah1*, Mukhlis ${ }^{2}$}

1,2 Graduate students of UIN Sunan Gunung Jati Bandung, Indonesia

\section{ART I CLE IN F O}

Article history:

Received June 23, 2021

Revised June 25, 2021

Accepted September 30, 2021

Available online October 25, 2021

Kata Kunci:

Kecerdasan Emosional, Prestasi Belajar

Keywords:

Emotional Intelligence, Learning Achievement

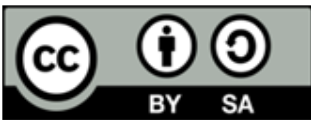

This is an open access article under the CC BY-SA license.

Copyright $(2021$ by Author. Published by Universitas Pendidikan Ganesha.

\begin{abstract}
ABST RAK
Dalam suatu pembelajaran tercapai atau tidaknya tujuan pembelajaran akan tercermin dari prestasi belajar siswa. Salah satu faktor dari dalam diri siswa yang menentukan prestasi belajar adalah kecerdasan emosional. Penelitian ini bertujuan untuk mengetahui hubungan antara kecerdasan emosional dengan prestasi belajar siswa. Penelitian ini tergolong penelitian expostfacto, dengan populasi penelitian adalah siswa SMP. Pengambilan sampel dalam penelitian ini dilakukan dengan menggunakan teknik non-probability sampling, dengan sampel akhir sebanyak 56 siswa SMP. Pengumpulan data dalam penelitian ini dilakukan dengan menggunakan metode pencatatan dokumen prestasi belajar dan metode non tes serta wawancara untuk mengetahui kecerdasan emosional siswa. Data penelitian dianalisis menggunakan teknik analisis data korelasi Product Moment dari Karl Pearson dengan bantuan SPSS versi 25. Hasil analisis akan menentukan hubungan antara kecerdasan emosional dengan prestasi belajar. Hasil yang diperoleh dalam penelitian ini menunjukkan nilai signifikansi 0,019 <0,050 yang berarti ada hubungan antara kecerdasan emosional dengan prestasi belajar siswa. Penelitian ini juga menunjukkan nilai koefisien productmoment sebesar 0,736 yang berarti ada hubungan antara kecerdasan emosional dengan prestasi belajar siswa. Kemudian, berdasarkan hasil tersebut, terdapat hubungan yang signifikan antara kecerdasan emosional dengan prestasi belajar siswa.
\end{abstract}

\section{A B S T R A C T}

In a study, whether or not the learning objectives are achieved will be reflected in students' learning achievements. One of the factors from within students that determines learning achievement is emotional intelligence. This study aimed to determine the relationship between emotional intelligence and student achievement. This research is classified as expostfacto research, with the research population being junior high school students. Sampling in this study was carried out using a nonprobability sampling technique, with a final sample of 56 junior high school students. Data collection in the study was carried out using the document recording method for learning achievement and non-test methods and interviews to determine students' emotional intelligence. The research data were analyzed using the Product Moment correlation data analysis technique from Karl Pearson with the help of SPSS 25 versions. The analysis results will determine the correlation between emotional intelligence and learning achievement. The results obtained in this study showed a significant value of $0.019<0.050$, which meant a correlation between emotional intelligence and students' achievement. This study also showed the product-moment coefficient value of 0.736 , which meant a correlation between emotional intelligence and student achievement. Then, based on these results, there was a significant relationship between emotional intelligence and student achievement.

\section{INTRODUCTION}

Education is a mode to improve the quality of human resources because of the success of the world of education as a determining factor in achieving the education's goal, namely educating the citizens (Suhendro, 2020; Sujana, 2019). It needed to face the sophisticated and competitive global era (Dewi, 2019; Lestari, 2018). Therefore, education plays a very important role in human life to realize progress and prosperity. Therefore, education cannot be separated from human life (Cikka, 2020; Wiyono et al., 2019). There is a relationship between educators and learners in learning (Jumrawarsi \& Suhaili, 2021). Educators shape the learners' character and behaviour patterns (Minsih \& D, 2018; Nuraida, 2019; Suwardi \& Farnisa, 
2018). Formal education results will show a positive learning change to acquire new skills, abilities, and knowledge (Rahmadana \& Ichsan, 2021; Sarwanto et al., 2019). Changes due to the learning process known by the term learning achievement.

Learning achievement is an effort or activity to master the subject matter that teachers provide in school (Riinawati, 2021; Umar, 2020; Yulika, 2019). Learning achievement is the result students obtain in the learning process (Rahmadana \& Ichsan, 2021; Shafi'i et al., 2018). Learning achievement is a term that individuals have achieved as an experienced activity that aims to acquire knowledge, skills, intelligence, and proficiency in certain conditions and situations (Arifandi, 2018; Istianah, 2019). Students have had learning achievements if they can achieve the learning goals (Santosa et al., 2020; Sodik et al., 2019). Student learning achievement becomes one of the benchmarks for the success of the learning process. Then, various factors that support the success of the learning process should become the focus of teachers and parents (Santosa et al., 2020). The support factor comes from inside and outside the learners. The intrinsic factor is the characteristics of the learners themselves, which include ability, attitude, motivation, learning habits, and emotional intelligence, while the extrinsic factor is the learning environment, learning resources, learning strategies, and others (Lagili et al., 2021; Utami et al., 2020; Yulika, 2019). One factor that determines the success of students learning is emotional intelligence.

Emotional intelligence becomes one of the important factors in the learning process. This is because emotional intelligence is an emotional ability that includes self-control, endurance when facing a problem, control impulses, self-motivated, mood, empathy, and managing relationships with others (Divine et al., 2018; Sarnoto \& Romli, 2019; Sunarti, 2018). Emotional intelligence can put someone's emotions in the right portion, sort out satisfaction and control the mood. Mood control is at the core of good social relationships (Alfian et al., 2020; Mulia \& Said, 2019). If a person is good at adjusting to the mood of other individuals or can empathize, the person will have a good level of emotionality and will more easily adjust to the social association and environment (Hafsah, 2021; Divine et al., 2018; Mulia \& Said, 2019). Students with good emotional intelligence will certainly be easier to get along with friends and master teaching material (Hastuti \& Baiti, 2019). This shows that not all students can control their emotions well (Ayuningtiyas et al., 2020). The lack of students' ability to control emotions in learning activities decreases student learning achievement. This is in line with the results of observations and interviews that have been conducted at MI Bongas IV Cililin West Bandung. Observations and interviews showed that students often are frustrated to complete assignments and homework given by teachers, which they are not serious about. Students had low emotional intelligence. Therefore, they could not survive in doing tasks as students. In addition, there were also found some students who did not get along with their classmates. It will affect the continuity of interaction in the classroom. For example, when working in groups, they have difficulty in communication. Well, it can be emphasized that emotional intelligence plays a role in the success of the learning process.

Some studies that have been done before revealed an influence of emotional intelligence on the students' results in learning mathematics (Setyawan \& Simbolon, 2018). The results of other studies also revealed a positive relationship between emotional intelligence and learning outcomes (Mulyati \&Farkhah, 2020). A third relevant study also revealed a significant positive relationship between emotional intelligence and junior high school students (Sitiman, 2021). Based on some previous studies, it can be concluded that emotional intelligence significantly influences student learning outcomes. However, there has been no study on the relationship between emotional intelligence and student learning achievement at MI Bongas IV Cililin West Bandung in the previous studies. Thus, this study focuses on finding out the relationship between emotional intelligence and learning achievement in MI Bongas IV Cililin West Bandung students.

\section{METHOD}

This study is expostfacto research that examines the relationship between emotional intelligence and student learning achievement. The independent variable was emotional intelligence, while the dependent variable was student learning achievement. Expostfacto research is an approach without a treatment to bring up the variables you want to research in the subject of the study, which is done to uncover the relationship of two or more variables without manipulation. This research was conducted at MI Bongas IV Cililin West Bandung with a population of all MI Bongas IV Cililin West Bandung students. The sample was collected using a nonprobability sampling technique (unknown population), which provides an equal opportunity for each element (member of the population) to be selected into a sample. Then, the current research used the Simple Random Sampling method. A population sampling was done randomly without regard to the strata in the population. The criteria used to determine the sample are grade VII and VIII students who have received school report cards. Thus, the sample in this study was 56 students. Data 
collection used document recording methods for learning achievement and non-test methods and interviews to determine students' emotional intelligence. The data was analyzed using the Product Moment correlation data analysis technique from Karl Pearson with the help of SPSS 25 versions. The analysis results would be used to find out the correlation between emotional intelligence and learning achievement.

\section{RESULT AND DISCUSSION}

\section{Result}

The research analysis began with the Pearson product-moment test. Pearson Product Moment test is used to determine the degree of relationship of 2 variables that scale intervals or ratios. This test will return the correlation coefficient value between $-1,0$ and 1 . Value -1 means a perfect negative correlation, 0 means no correlation, and 1 means a perfect positive correlation. Test results showed a significant value of $0.019<0.050$. It showed a correlation between emotional intelligence and learning achievement in grade VII and VIII students at MI Bongas IV Cililin West Bandung. To see the level of correlation between the two variables, it can be known that the value of the product-moment coefficient is 0.736 . It showed that the correlation between emotional intelligence and learning achievement in MI Bongas IV Cililin West Bandung students is categorized as substantial. After conducting a hypothesis test to determine how much the influence of $\mathrm{X}$ variable has on $\mathrm{Y}$ variable expressed in percentage form. The Coefficient of Determination test is carried out. The Coefficient of Determination test results showed that the coefficient of determination (R2) value of 0.418 or $41.8 \%$. It meant that the ability of the emotional intelligence determination model was able to explain other variables that influenced $41.8 \%$ of learning achievement and the remaining $57.2 \%$.

\section{Discussion}

The data analysis from the research results showed that emotional intelligence became one-factor affecting student learning achievement. This is because emotional intelligence indicates the students' emotional ability, which includes the ability to control themselves, have endurance when facing a problem, able to control impulses, motivate themselves, be able to control mood, empathize and manage relationships with others (Divine et al., 2018; Mulyati \& Farkhah, 2020; Setyawan \& Simbolon, 2018; Sitiman, 2021). Emotional intelligence can put one's emotions in the right portion, sort out satisfaction and control the mood. Mood control is at the core of good social relations (Utami et al., 2020; Wiyono et al., 2019). Suppose a person is good at adjusting to the mood of other individuals or can empathize. In that case, the person will have a good level of emotionality and will more easily adjust to the social association and environment (Lagili et al., 2021). A child who can control his emotions well will interact well with his friends, teachers, and people in his environment (Hastuti \& Baiti, 2019; Istianah, 2019). Good interaction between learners with learning resources with peers will make learners more comfortable in the learning process.

The existence of good interaction between peers will make learners appreciate each other and can eliminate feelings of anxiety. Peers help guide and support their peers to build learning through interaction and collaboration (Andersen \&Watkins, 2018). In addition, learning involving peers will reduce anxiety, by being guided, helped, and given feedback by fellow learners will be able to increase confidence (Han et al., 2015; Stone et al., 2013) and learning with peers will encourage learners to play an active role in learning (Oh, 2019). Being active in the learning process will provide more learning experiences to learners, which will certainly impact their learning achievement. Learning achievement is an effort or activity to master the subject matter teachers provide in school (Rinawati, 2021; Umar, 2020; Yulika, 2019). Learning achievement is the students' results obtained in the learning process (Rahmadana \& Ichsan, 2021; Shafi'i et al., 2018). Learning achievement is a term that individuals have achieved as an experienced activity that aims to acquire knowledge, skills, intelligence, and proficiency in certain conditions and situations (Arifandi, 2018; Istianah, 2019). Students are known to have had learning achievements if the student has been able to achieve learning goals (Santosa et al., 2020; Sodik et al., 2019). Therefore, to support the achievements, teachers must understand the factors that determine the success of the learning process.

The results obtained in this study align with some previous studies. The study results also revealed an influence of emotional intelligence on students' mathematic learning outcomes (Setyawan \& Simbolon, 2018). The other studies also revealed a positive relationship between emotional intelligence and learning outcomes (Mulyati \&Farkhah, 2020). A third relevant study also revealed a significant positive relationship between emotional intelligence and junior high school students (Sitiman, 2021). Based on the research results supported by previous studies, the result can be concluded that students' emotional intelligence will affect the students' achievement and learning outcomes. 


\section{CONCLUSION}

There is a significant relationship between emotional intelligence and student learning achievement. The existence of good emotional intelligence will allow learners to control themselves in the learning process to create a conducive learning environment. The suggestions that can be given are teachers and parents can be focused on students' emotions when the learning process is carried out to improve the learning achievement of each learner.

\section{REFERENCES}

Alfian, M. R., Kaukab, M. E., \& Romandhon, R. (2020). Peran Kecerdasan Spiritual Dan Emosional Mahasiswa Dalam Memahami Ilmu Akuntansi. Paramurobi: Jurnal Pendidikan Agama Islam, 3(1), 35-45. Https://Doi.Org/10.32699/Paramurobi.V3i1.1432.

Andersen, T., \& Watkins, K. (2018). The Value Of Peer Mentorship As An Educational Strategy In Nursing. Journal Of Nursing Education, 57(4), 217-224. Https://Doi.Org/10.3928/01484834-2018032205.

Arifandi, A. S. D. (2018). Alat Penunjang Dalam Prestasi Belajar. Edukais : Jurnal Pemikiran Keislaman, 2(2), 161-172. Https://Doi.Org/10.36835/Edukais.2018.2.2.161-172.

Ayuningtiyas, C., Fitriana, S., \& Dian, M. P. (2020). Regulasi Emosi Siswa Dalam Pembelajaran Daring. Dharmas Education Journal, 1(2), 107-113.

Cikka, H. (2020). Konsep-Konsep Esensial Dari Teori Dan Model Perencanaan Dalam Pembangunan Pendidikan. Scolae: Journal Of Pedagogy, 3(2).

Dewi, E. (2019). Potret Pendidikan Di Era Globalisasi Teknosentrisme Dan Proses Dehumanisasi. Sukma: Jurnal Pendidikan, 3(1), 93-116. Https://Doi.Org/10.32533/03105.2019.

Hafsah, I. (2021). Peningkatan Kemampuan Emosi Melalui Story Book (Tk Yaa Bunayya Ngawi Tahun Ajaran 2018/2019). Journal Of Modern Early Childhood Education, 1(01), 25-35.

Han, J.-S., Baek, H. C., \& Jeong, A.-S. (2015). The Effects Of Psychiatric Nursing Simulation On Anxiety And Self-Confidence About Clinical Placement Of Nursing Students. Journal Of The Korea Academia$\begin{array}{llll}\text { Industrial } & \text { Cooperation } & \text { Society, } & \text { 16(11), }\end{array}$ Https://Doi.Org/10.5762/Kais.2015.16.11.7812.

Hastuti, R. Y., \& Baiti, E. N. (2019). Hubungan Kecerdasan Emosional Dengan Tingkat Stress Pada Remaja. Jurnal Ilmiah Kesehatan, 8(2). Https://Doi.Org/Https://Doi.Org/10.52657/Jik.V8i2.1057.

Illahi, U., Neviyarni, N., Said, A., \& Ardi, Z. (2018). Hubungan Antara Kecerdasan Emosi Dengan Perilaku Agresif Remaja Dan Implikasinya Dalam Bimbingan Dan Konseling. Jrti (Jurnal Riset Tindakan Indonesia), 3(2), 68. Https://Doi.Org/10.29210/3003244000.

Istianah. (2019). Pengaruh Kecerdasan Emosional Dan Minat Belajar Siswa Terhadap Prestasi Belajar Ilmu Pengetahuan Sosial. Jurnal Pemikiran Dan Pendidikan Dasar Islam, 2(2). Https://Doi.Org/Https://Doi.Org/10.51476/Dirasah.V2i2.105.

Jumrawarsi, J., \& Suhaili, N. (2021). Peran Seorang Guru Dalam Menciptakan Lingkungan Belajar Yang Kondusif. Ensiklopedia Education Review, 2(3), 50-54. Https://Doi.Org/10.33559/Eer.V2i3.628.

Lagili, I. L., Pomalato, S. W. D., \& Pakaya, A. R. (2021). Hubungan Kecerdasan Emosional Dan Motivasi Belajar Dengan Hasil Belajar Siswa Pada Mata Pelajaran Ekonomi Kelas Xi Di Sma Negeri 3 Gorontalo. Jurnal Normalita, 9(1).

Lestari, S. (2018). Peran Teknologi Dalam Pendidikan Di Era Globalisasi. Edureligia; Jurnal Pendidikan Agama Islam, 2(2), 94-100. Https://Doi.Org/10.33650/Edureligia.V2i2.459.

Minsih, M., \& D, A. G. (2018). Peran Guru Dalam Pengelolaan Kelas. Profesi Pendidikan Dasar, 1(1), 20. Https://Doi.Org/10.23917/Ppd.V1i1.6144.

Mulia, S. W., \& Said, A. (2019). Relationship Of Emotional Maturity With Social Interaction Of Student In Smp N 1 Ranah Batahan Pasaman Barat. Jurnal Neokonseling, 1(4). Https://Doi.Org/10.24036/00158kons2019.

Mulyati, B., \& Farkhah, E. (2020). Hubungan Kecerdasan Emosional Terhadap Hasil Belajar Siswa. Progress: Jurnal Pendidikan, Akuntansi Dan Keuangan, 3(1), 42-51. Https://Doi.Org/10.47080/Progress.V3i1.773.

Nuraida, D. (2019). Peran Guru Dalam Mengembangkan Keterampilan Berpikir Kritis Siswa Dalam Proses Pembelajaran. Jurnal Teladan: Jurnal Ilmu Pendidikan Dan Pembelajaran, 4(1), 51-60.

Oh, E. (2019). Research On The Effective Of Peer Instruction And Students' Involvement. Asia-Pacific Of Multimedia Services Convergent With Art Humanities, And Sociology, 9, 199-208. Https://Doi.Org/Https://Doi.Org/10.35873/Ajmahs.

Rahmadana, J., \& Ichsan, I. (2021). Pengaruh Tingkat Pendidikan Orang Tua Terhadap Prestasi Belajar Anak Sekolah Dasar. Waniambey: Jurnal Pendidikan Dasar Islam, 2(2), 69-78. 
Https://Doi.Org/10.53837/Waniambey.V2i2.182.

Riinawati, R. (2021). Hubungan Konsentrasi Belajar Siswa Terhadap Prestasi Belajar Peserta Didik Pada Masa Pandemi Covid-19 Di Sekolah Dasar. Edukatif: Jurnal Ilmu Pendidikan, 3(4), 2305-2312. Https://Doi.Org/10.31004/Edukatif.V3i4.886.

Santosa, D. S. S., Sampaleng, D., \& Amtiran, A. (2020). Meningkatkan Prestasi Belajar Siswa Melalui Model Pembelajaran. Sikip: Jurnal Pendidikan Agama Kristen, 1(1), 11-24. Https://Doi.Org/10.52220/Sikip.V1i1.34.

Sarnoto, A. Z., \& Romli, S. (2019). Pengaruh Kecerdasan Emosional (Eq) Dan Lingkungan Belajar Terhadap Motivasi Belajar Siswa Sma Negeri 3 Tangerang Selatan. Andragogi: Jurnal Pendidikan Islam Dan Manajemen Pendidikan Islam, 1(1), 55-75. Https://Doi.Org/10.36671/Andragogi.V1i1.48.

Sarwanto, A., Setyawan, D. A., \& Setyaningsih, W. (2019). Study Korelasi Faktor-Faktor Yang Berhubungan Dengan Kualitas Hasil Belajar Melalui Orientasi Masa Depan Pada Mahasiswa Politeknik Kesehatan Surakarta Tahun 2017. Jurnal Keterapian Fisik, 4(2), 71-77. Https://Doi.Org/10.37341/Jkf.V4i2.183.

Setyawan, A. A., \& Simbolon, D. (2018). Pengaruh Kecerdasan Emosional Terhadap Hasil Belajar Matematika Siswa Smk Kansai Pekanbaru. Jurnal Penelitian Dan Pembelajaran Matematika, 11(1). Https://Doi.Org/10.30870/Jppm.V11i1.2980.

Sitiman, H. La. (2021). Hubungan Antara Kecerdasan Emosional Dan Motivasi Belajar Dengan Hasil Belajar Ipa Siswa Smp Negeri 1 Sungguminasa. Jurnal: Kamboti Of Journal Education Research And Development, 4(1), 6 .

Sodik, M., Sahal, Y. F. D., \& Herlina, N. H. (2019). Pengaruh Kinerja Guru Dalam Pelaksanaan Pembelajaran Terhadap Prestasi Belajar Siswa Pada Mata Pelajaran Alquran Hadis. Jurnal Penelitian Pendidikan Islam, 7(1), 97. Https://Doi.Org/10.36667/Jppi.V7i1.359.

Stone, R., Cooper, S., \& Cant, R. (2013). The Value Of Peer Learning In Undergraduate Nursing Education: A Systematic Review. In Nursing, 2013(I), 1-10. Https: //Doi.Org/10.1155/2013/930901.

Suhendro, E. (2020). Strategi Pembelajaran Pendidikan Anak Usia Dini Di Masa Pandemi Covid-19. Jurnal Ilmiah Tumbuh Kembang Anak Usia Dini. Https:// Doi.Org/10.14421/Jga.2020.53-05.

Sujana, I. W. C. (2019). Fungsi Dan Tujuan Pendidikan Indonesia. Adi Widya: Jurnal Pendidikan Dasar, 4(1), 29. Https://Doi.Org/10.25078/Aw.V4i1.927.

Sunarti, I. (2018). Pengaruh Kecerdasan Emosi, Efikasi Diri Dan Motivasi Belajar Terhadap Prestasi Belajar Mahasiswa Pendidikan Ekonomi Uniku (Survei Pada Mahasiswa Semester Ganjil 2017-2018 Pendidikan Ekonomi Universitas Kuningan). Jurnal Penelitian Pendidikan Dan Ekonomi, 15(2). Https://Doi.Org/10.25134/Equi.V15i02.1616.

Suwardi, I., \& Farnisa, R. (2018). Hubungan Peran Guru Dalam Proses Pembelajaran Terhadap Prestasi Belajar Siswa. Jurnal Gentala Pendidikan Dasar, 3(2), 181-202. Https://Doi.Org/10.22437/Gentala.V3i2.6758.

Syafi'i, A., Marfiyanto, T., \& Rodiyah, S. K. (2018). Studi Tentang Prestasi Belajar Siswa Dalam Berbagai Aspek Dan Faktor Yang Mempengaruhi. Jurnal Komunikasi Pendidikan, 2(2), 115. Https://Doi.Org/10.32585/Jkp.V2i2.114.

Umar, M. (2020). Peranan Orang Tua Dalam Meningkatkan Prestasi Belajar Anak. Musawa: Journal For Gender Studies, 12(1), 108-139. Https://Doi.Org/10.24239/Msw.V12i1.591.

Utami, S. A., Damayanti, E., \& Ismail, W. (2020). Pengaruh Kecerdasan Emosional Terhadap Hasil Belajar Biologi Peserta Didik. Psikoislamedia: Jurnal Psikologi, 5(1), 1. Https://Doi.Org/10.22373/Psikoislamedia.V5i1.6138.

Wiyono, A., Anggo, M., \& Kadir, K. (2019). Pengaruh Kecerdasan Emosional Terhadap Hasil Belajar Matematika Siswa Kelas Viii Mts Negeri 1 Kendari. Jurnal Penelitian Pendidikan Matematika, 6(2), 113. Https: //Doi.Org/10.36709/Jppm.V6i2.9121.

Yulika, R. (2019). Pengaruh Kecerdasan Emosi Dan Motivasi Belajar Terhadap Prestasi Belajar Siswa Di Smp Negeri 1 Sengkang. Jurnal Inspirasi Pendidikan, 8(2). Https://Doi.Org/10.24252/Ip.V8i2.7838. 